\title{
ANALYSIS OF COMPLAINTS ON RIBBED BARS AS A TOOL FOR QUALITY ANALYSIS
}

\author{
${ }^{1}$ Manuela INGALDI, ${ }^{2}$ Szymon T. DZIUBA \\ ${ }^{1}$ Czestochowa University of Technology, Faculty of Management, Czestochowa, Poland, EU \\ manuela.ingaldi@wz.pcz.pl, manuela@gazeta.pl \\ ${ }^{2}$ Wroclaw University of Economics, Faculty of Engineering and Economics, Wroclaw, Poland, EU \\ szymon.dziuba@ue.wroc.pl
}

https://doi.org/10.37904/metal.2019.777

\begin{abstract}
Ribbed bars, like other metallurgical products, must meet the relevant requirements resulting from standards and specified by customers in their orders. The following dimensions of ribbed bars are specified in the standards: nominal diameter and their permissible deviations, mass range of $1 \mathrm{~m}$ of ribbed bar, core diameter, rib height, width and length of ribs longitudinal. For individual steel grades, their chemical composition is also defined. The requirements regarding mechanical properties, plasticity and weldability are also specified. Complaints can be treated as one of the tools which gives a lot of information about product quality, even if they are often overlooked in the qualitative analysis. In complaints customers describe the problems they encountered. These problems and their causes should be analyzed and eliminated by the enterprise. Professional complaints management can be treated as an important element of the product quality improvement system. The enterprise not only adjusts knowledge about the quality of its products in this way, but also obtains feedback from customers about these products. The purpose of the articles was to analyze complaints regarding ribbed bars filed by customers of one of the steelworks in Poland. The analysis was based on data from five consecutive years. The percentage of complaints considered by the producer as justified was also presented.
\end{abstract}

Keywords: Quality, quality analysis, complaints, ribbed bars

\section{INTRODUCTION}

Mistakes, including production mistakes, are inherent in any human activity. Production free of mistakes and defective products is very rare. Therefore, companies use various tools and methods of quality control. It should be noted that with the lack of control of $100 \%$ products, some defective items can be overlooked and sent to the customer [1,2]. Products purchased by customers and used by them may be subject to various types of failures and breakdowns. The problem occurs when, for example, a new product, which is often under warranty, is damaged. Then the customer makes a complaint about such a product and the problem. In complaints, customers describe the problem and expect to eliminate it $[3,4]$. A complaint is an expression of dissatisfaction lodged to an organization, related to its products or the complaint handling process itself, where a response or solution is expected or required [5]. It can be concluded from this definition that is the customer's reaction to the failure to meet their expectations in relation to the product. As argued by Balon [6], complaints are a means of communication between the customer and the enterprise in order to notify the latter of the insufficient quality of products or services. They are also an important element of management in the organization. Complaints have become the main means of a direct contact between organizations and companies with their customers. They started to develop and teach rules on how to deal with customers, focusing on the improvement of customer service. The following terms were developed: comprehensive customer service, customer satisfaction index, customer orientation and many others, putting the customer at the centre of attention. An in-depth analysis of the complaints allows for finding their causes to make improvements in a broad sense of the term. In the old days, manufacturers were afraid of complaints and considered them a necessary evil. Therefore, a lengthy procedure, a complicated complaint form or a hostile 
employee accepting complaints were supposed to discourage customers from lodging them. This was not a good approach, because product quality was not improved while the level of customer satisfaction was decreasing, which led to customers choosing other companies [7]. Therefore, most companies have modified their attitudes, treating complaints as an element of quality analysis, as feedback from the customer concerning or not the customer's requirements. This is because complaints lodged by customers are the most effective way to obtain information about the quality of their own products.

Processing complaints gives the opportunity to maintain and increase customer loyalty, strengthen and improve competitiveness. This can be achieved by implementation of the ISO 10002:2014 standard. Its implementation will increase the ability to solve problems included in complaints, which may relate not only to single goods or services the customers complain about, but also to the entire range of products. The implementation of the standard will ensure consistent and systematic solving the problems by identification of the trends and elimination of the causes of complaints, which is associated with a general improvement in business. It is also important to raise awareness and encourage employees to provide comprehensive customer services in terms of complaints, so that the organization can improve the processes of making products, providing services and improving their quality (ISO 10002:2014, 2014). The standard indicates that the strength of the organization depends on the customer, because there is no definition of the physical condition of the product but the customer's perception, i.e. their subjective opinion. It is determined by the approach to the complaint from the standpoint of feedback rather than a single claim for damages [5].

Thus the complainant chooses to communicate with the company with regard to problematic experiences related to the consumption or use of the product, rather than simply giving up being a customer, which gives the company the opportunity to provide a kind of countermeasures and/or to take certain corrective actions concerning its processes [8]. Therefore, this represents a value added for the company. It is likely that the complaint can help the company retain the customer. Information flow management is extremely important in the aspect of the entire supply chain. With complaints, the company is able to analyze information about the quality of products, respond appropriately, and meet the expectations of customers and improve its products. If the company accepts complaints, and it attempts to meet the expectations of customers, the latter will be willing to pay more for the products offered, and even come back for other products of the same manufacturer [9]. Therefore, it can be emphasized that a complaint means that the company should analyze the problem and eliminate it. Detailed quality control of individual products is also conducted in such companies as steelworks. This control provides the results showing the performance of a given batch of products in the form of basic performance measures. However, these measures do not always give a sufficiently complete picture of the achieved or planned level of a product or process quality. In such situations, the need arises for definition of new measures that provide the basis for decision-making related to control and management of the process of creating and ensuring quality. Various indicators of the intensity of quality complaints are used particularly often for this purpose. These indicators provide valuable information about the market response to the offered products and are a natural supplementation to the distribution of consumer preferences which characterize the marketing quality of the product. The indicators should be treated as characterization of the level of performance quality because it should be assumed that the buyer accepted the quality of the product type.

The aim of the paper was to analyze complaints lodged by customers of one of the steelworks in Poland (the bar rolling mill of this steelworks) concerning ribbed bars. The analysis was based on the data from five consecutive years. The percentage of complaints accepted by the manufacturer and the reasons for complaints were also presented.

\section{QUALITY OF THE RIBBED BARS}

In recent years, more and more investments in modern construction have been made in Poland. First of all, the investments concern new roads and motorways. Therefore, the construction sector shows an increasing demand for metallurgical products of shape mills, e.g. for ribbed bars for reinforced concrete. The ribbed bars, 
like other metallurgical products, must meet the relevant requirements resulting from standards and specified by customers in their orders. The following dimensions of ribbed bars are specified in the standards: nominal diameter and their permissible deviations, mass range of $1 \mathrm{~m}$ of ribbed bar, core diameter, rib height, width and length of ribs longitudinal. For individual steel grades, their chemical composition is also defined. The requirements regarding mechanical properties, plasticity and weldability are also specified. These properties are obtained due to their properly carried out production process [10]. All the required parameters are subject to a detailed inspection. The purpose of this control is to eliminate defective products from individual production batches, but also to eliminate the causes of these inconsistencies in order to prevent their reappearance. During the inspection in the tested enterprise, various instruments are used to analyze the measurement results, such as basic statistics, control cards, quality capability indicators, which allow for the evaluation of the overall quality level of the produced bars [11]. Since the inspection of ribbed bars in the facility studied is not a $100 \%$ inspection but a sampling check, there is a risk (but to a very little degree) that non-compliant products will be shipped to the customer. Therefore, the results of internal control do not reflect in $100 \%$ the level of quality of manufactured products. It is therefore necessary to analyze the complaints lodged by customers relating to defective ribbed bars.

\section{METHODOLOGY}

The study was conducted in a bar rolling mill in one of the steelworks in Poland. The rolling mill offers a wide range of bars. Ribbed bars, which are one of the key products, were selected for the study. The rolling mill manufactures 12 different diameters of ribbed bars. The standard length of the bars is $12 \mathrm{~m}$. It is possible to manufacture bars with a length of 6 to $18 \mathrm{~m}$ at the request. The quality tests of ribbed bars are conducted on a large scale and all the requirements contained in standards and customer orders are taken into account. Complaints are being examined but so far no analysis of this problem has been done. The data for the study were derived from the register of complaints kept in the rolling mill. The examined complaints and the related data concerned only the ribbed bars. At the beginning, the complaint analysis was conducted with the division into the consecutive years. Next, a similar analysis was made with regard to the steel grade. Finally, the complaint was analyzed with consideration for the reasons for lodging them. The analysis provides information about the most common causes of complaints and the extent to which the complaints were accepted by the rolling mill employees.

\section{RESULTS}

The paper presents the structure of complaints over five consecutive years. Table 1 shows the number of complaints in individual years.

Table 1 Number of complaints in individual years of the research period [own study]

\begin{tabular}{|l|c|c|c|c|c|}
\hline \multirow{2}{*}{ Element } & \multicolumn{5}{|c|}{ Years } \\
\cline { 2 - 6 } & $\mathbf{1}$ & $\mathbf{2}$ & $\mathbf{3}$ & $\mathbf{4}$ & $\mathbf{5}$ \\
\hline Number of complaints lodged [Mg] & 54.42 & 229.29 & 36.40 & 3622.14 & 126.61 \\
\hline Number of complaints accepted [Mg] & 37.50 & 192.60 & 4.87 & 3605.69 & 85.00 \\
\hline Ratio of accepted to lodged complaints [\%] & 68.91 & 84.00 & 13.38 & 99.55 & 67.14 \\
\hline
\end{tabular}

Apart from the fourth year included in the analysis, the number of complaints was small. In the fourth year, one of the customers filed a large complaint, which affected the overall size of all complaints. Furthermore, the number of complaints accepted in this year was the highest. The register of complaints does not show which sections they concerned, so it is impossible to analyse the complaints for individual ribbed bar sections. The complaint rate was then calculated by dividing the number of complaints by total production and giving the 
value as a percentage. Similar principles were used to calculate the index of complaints accepted. Results of these calculations are presented in Table 2.

Table 2 Complaint ratio compared to total production for individual years [own study]

\begin{tabular}{|l|c|c|c|c|c|}
\hline \multirow{2}{*}{ Element } & \multicolumn{5}{|c|}{ Years } \\
\cline { 2 - 6 } & $\mathbf{1}$ & $\mathbf{2}$ & $\mathbf{3}$ & $\mathbf{4}$ & $\mathbf{5}$ \\
\hline Total production [Mg] & 386875 & 380044 & 443958 & 470667 & 403185 \\
\hline Ratio of complaints lodged [Mg] & 0.0141 & 0.0603 & 0.0082 & 0.7696 & 0.0314 \\
\hline Ratio of complaints accepted [Mg] & 0.0097 & 0.0507 & 0.0011 & 0.7661 & 0.0211 \\
\hline
\end{tabular}

Table 3 The number of complaints for individual steel grades in the entire period [own study]

\begin{tabular}{|l|c|c|c|c|}
\hline \multirow{2}{*}{ Element } & \multicolumn{4}{|c|}{ Steel grade } \\
\cline { 2 - 5 } & 18G2-b & 34GS & BSt500S & BSt500SV \\
\hline Number of complaints lodged [Mg] & 43.27 & 134.29 & 3855.07 & 36.23 \\
\hline Number of complaints accepted [Mg] & 37.50 & 33.72 & 3722.21 & 36.23 \\
\hline $\begin{array}{l}\text { Ratio of accepted to lodged } \\
\text { complaints [\%] }\end{array}$ & 86.67 & 25.11 & 96.55 & 100.00 \\
\hline
\end{tabular}

Table 4 The causes of complaints grades in the entire period [own study]

\begin{tabular}{|c|c|c|c|}
\hline Element & $\begin{array}{l}\text { Number of } \\
\text { complaints } \\
\text { lodged [Mg] }\end{array}$ & $\begin{array}{c}\text { Number of } \\
\text { complaints } \\
\text { accepted [Mg] }\end{array}$ & $\begin{array}{l}\text { Ratio of accepted to } \\
\text { lodged complaints [\%] }\end{array}$ \\
\hline Insufficient filling of the bar cross-section & 7.95 & 1.20 & 15.09 \\
\hline curved ends, bent ends, incorrect cutting length & 3550.00 & 3550.00 & 100.00 \\
\hline non-dimensional length, deformed ends & 26.49 & 26.49 & 100.00 \\
\hline Incorrect chemical composition & 2.55 & 2.55 & 100.00 \\
\hline reduced $\mathrm{Re}$ & 163.42 & 163.42 & 100.00 \\
\hline cracking at bending ${ }^{1)}$ & 128.84 & 32.52 & 25.24 \\
\hline longitudinal cracking, cracking at bending & 4.24 & 0.00 & 0.00 \\
\hline longitudinal cracks & 3.28 & 0.00 & 0.00 \\
\hline crooked bundles & 4.25 & 4.25 & 100.00 \\
\hline oval bars & 24.67 & 24.67 & 100.00 \\
\hline oval bars, cracking at bending & 24.67 & 0.00 & 0.00 \\
\hline delamination & 5.44 & 5.44 & 100.00 \\
\hline flattened bars & 1.50 & 1.50 & 100.00 \\
\hline greasy spots & 23.52 & 23.52 & 100.00 \\
\hline outflows, reduced $\mathrm{Re}$ & 1.59 & 1.59 & 100.00 \\
\hline shipment not in accordance with the request & 5.68 & 5.68 & 100.00 \\
\hline curved ends & 90.77 & 85.00 & 93.64 \\
\hline
\end{tabular}

(1) considered for other reasons - different chemical composition

Analysis of the results shows that the highest value of indicators was recorded in the fourth year analysed, when both production and the number of complaints were the highest. However, their values did not exceed 
$1 \%$. It should be noted that this year was very specific, with a very large number of complaints. In the remaining analyzed years, the indicators did not exceed $0.1 \%$.

Table 3 shows the structure of the complaints by the steel grade from which the bars were made. The complaints concerned only four steel grades which are most commonly used for the production of ribbed bars. The most frequent complaints concerned BSt500S steel, but it should be noted that this is the most popular steel. In the case of BSt500SV, all complaints were accepted. Table 4 presents the basic causes of complaints lodged by customers. The cause which concerned the highest number of bars was "curved ends, bent ends, incorrect cutting length". As in the previous two tables, this concerned one customer. Table 3 shows that the complaint was accepted in $100 \%$, which is not entirely true as the complaint was only partially accepted. However, it is impossible to distinguish between the part of the complaint accepted and the part rejected by the steelworks. A complaint due to cracking at bending should also be emphasized. Such a cause is not accepted by the steelworks. In one case, the complaint was accepted, but the cause was changed to a different chemical composition than desired. In such cases, the steelworks stated that customers misused the product by improperly bending the bars, causing them to break. The steelworks considered other causes to be justified in most cases. In conclusion, the number of complaints is not high and does not have an effect on the overall assessment of the quality of the ribbed bars manufactured by the steelworks. It should be added that a large part of the complaints submitted by customers was justified.

\section{CONCLUSION}

The paper presented an analysis of complaints concerning ribbed bars lodged by customers of one of the steelworks in Poland. The study covered five consecutive years. In the fourth year studied, one large complaint was lodged, affecting the value of the calculated indicators, but this indicator did not exceed $1 \%$ of the total level of production of bars. In the remaining period, this ratio did not exceed $0.1 \%$, which means that the amount of bars the complaints concerned was similar and low. The most frequent complaints concerned bars made of BSt500S steel. Most complaints were lodged due to curved ends, bent ends and incorrect cutting length. In most cases, these complaints were accepted. The steelworks' employees did not accept complaints relating to longitudinal cracking and cracking at bending due to improper bending of the bars. It should be emphasized that the analysis of complaints is a valuable source of feedback from the customer on the quality of products sold. This analysis allows for evaluation how many defects were noticed by customers and what are the main causes of complaints about products, and, consequently, for implementation of corrective measures that will help eliminate such situations.

Results, methodology and obtained guidelines may be useful in similar cases of customers problems met in steel industry [12-14] as well as in other branch of industry e.g. dental materials [15], magnetic materials [16], chemical industry [17], biocoatings technology [18-20], technologicaly used coatings [21,22] or even in pharmaceuticals research $[23,24]$. Such situations may be also met even in service-oriented activities as an image analysis [25] where an objectivity if still imposed by individual interpretations.

\section{REFERENCES}

[1] BOSHOFF, C.R. An experimental study of service recovery options. International Journal of Service Industry Management 1997, vol. 8, pp. 110-130.

[2] KARDAS, E. The analysis of non-conformances as the way of assessment of quality of aluminium finishing strips in the selected company. MATEC Web of Conferences 2018, vol. 183, art. 03005.

[3] ULEWICZ R. Outsourcing quality control in the automotive industry. MATEC Web of Conferences 2018, vol. 183, art. 03001.

[4] MAZUR M. and MOMENI H. Lean production issues in the organization of the company - results. Production Engineering Archives 2019, vol. 22, pp.50-53. 
[5] ISO 10002:2014 Quality management -- Customer satisfaction -- Guidelines for complaints handling in organizations.

[6] BALON U. Zachowania młodych konsumentów wobec reklamacji a koszty w przedsiębiorstwie. Studia Ekonomiczne. Zeszyty Naukowe Uniwersytetu Ekonomicznego w Katowicach 2016, No 255, pp. 239-249.

[7] LAU, G.T. and NG, S. Individual and situational factors influencing negative word of mouth behavior. Revue Canadienne des Sciences de l'Administration 2001, vol. 18, pp. 163-178.

[8] FOLKES, V. S., KOLETSKY, S. and GRAHAM, J. L. A field study of causal inferences and consumer reaction. Journal of Consumer Research 1987, vol. 13, pp. 534-539.

[9] BARLOW J. and MOLLER C. Reklamacja jako prezent, Wydawnictwo Naukowe PWE, Warszawa 2001.

[10] INGALDI M. The evaluation of structure and destruction of ribbed bars as a result of processing and heat treatment. Materials Research Proceedings 2018, vol. 5 pp.111-116.

[11] SYGUT, P., KLIMECKA-TATAR, D. and BORKOWSKI, S. Theoretical analysis of the influence of longitudinal stress changes on band dimensions during continuous rolling process. Arch. Metall. Mater. 2016, vol. 61, pp.183188.

[12] ULEWICZ, R. and NOVY, F.R. The influence of the surface condition on the fatigue properties of structural steel. Journal of the Balkan Tribological Association 2016, vol. 22, pp. 1147-1155.

[13] LIPINSKI, T. Double modification of AISi9Mg alloy with boron, titanium and strontium. Arch. Metall. Mater. 2015, vol. 60, pp. 2415-2419.

[14] LIPINSKI, T. The effect of the diameter and spacing between impurities on the fatigue strength coefficient of structural steel. Arch. Metall. Mater. 2018, vol. 63, pp. 519-524.

[15] KLIMECKA-TATAR, D. Electrochemical characteristics of titanium for dental implants in case of the electroless surface modification. Arch. Metall. Mater. 2016, vol. 61, pp. 923-926.

[16] KLIMECKA-TATAR, D., PAWLOWSKA, G. and RADOMSKA, K. The effect of Nd12Fe77Co5B6 powder electroless biencapsulation method on atmospheric corrosion of polymer bonded magnetic material. In METAL 2014: 23 ${ }^{\text {rd }}$ Int. Conf. on Metallurgy and Materials. Ostrava: TANGER, pp. 985-990.

[17] PACANA, A., RADON-CHOLEWA, A., PACANA, J. and WOZNY, A. The study of stickiness of packaging film by Shainin method. Przemyst Chemiczny 2015, vol. 94, pp. 1334-1336.

[18] DUDEK, A. and KOLAN, C. Assessments of Shrinkage Degree in Bioceramic Sinters HA+ZrO(2). Solid State Phenom. 2010, vol. 165, 25-30.

[19] DUDEK, A. and WLODARCZYK, R. Structure and properties of bioceramics layers used for implant coatings. Solid State Phenom. 2010, vol. 165, pp. 31-36.

[20] DUDEK A. Investigations of microstructure and properties in bioceramic coatings used in medicine. Arch. Metall. Mater. 2011, vol. 56, pp. 135-140.

[21] SKONECZNY, W. and BARA, M. Aluminium oxide composite layers obtained by the electrochemical method in the presence of graphite. Materials Science-Poland 2007, vol. 25, pp. 1053-1062.

[22] BARA, M., SKONECZNY, W. and HAJDUGA, M. Ceramic-graphite surface layers obtained by the duplex method on an aluminium alloy substrate. Chemical and Process Engineering 2009, vol. 30, pp. 431-442.

[23] SKRZYPCZAK-PIETRASZEK, E., REISS, K., ZMUDZKI, P., PIETRASZEK, J. Enhanced accumulation of harpagide and 8-O-acetyl-harpagide in Melittis melissophyllum L. agitated shoot cultures analyzed by UPLCMS/MS. PLOS ONE 2018, vol.13, e0202556.

[24] SKRZYPCZAK-PIETRASZEK E., PISKA, K. and PIETRASZEK, J. Enhanced production of the pharmaceutically important polyphenolic compounds in Vitex agnus castus L. shoot cultures by precursor feeding strategy. Enginnering in Life Sciences 2018, vol. 18, pp. 287-297.

[25] SZCZOTOK, A., RADEK, N., DWORNICKA, R. Effect of the induction hardening on microstructures of the selected steels. In METAL 2018: 27th Int. Conf. Metallurgy and Materials. Ostrava: TANGER, 2018, pp. 12641269. 